\title{
Medicalization Discourse and Modernity: Contested Meanings Over Childbirth in Contemporary Turkey
}

\section{Dilek Cindoglu \& Feyda Sayan-Cengiz}

To cite this article: Dilek Cindoglu \& Feyda Sayan-Cengiz (2010) Medicalization Discourse and Modernity: Contested Meanings Over Childbirth in Contemporary Turkey, Health Care for Women International, 31:3, 221-243, DOI: 10.1080/07399330903042831

To link to this article: http://dx.doi.org/10.1080/07399330903042831

曲 Published online: 03 Feb 2010.

Submit your article to this journal $\llbracket$

Џلll Article views: 352

Q View related articles $\square$

Citing articles: 11 View citing articles 4 


\title{
Medicalization Discourse and Modernity: Contested Meanings Over Childbirth in Contemporary Turkey
}

\author{
DILEK CINDOGLU and FEYDA SAYAN-CENGIZ \\ Department of Political Science, Bilkent University, Bilkent, Ankara, Turkey
}

\begin{abstract}
In this article, we explore the increasing medicalization of birth and the surge in Caesarean sections in order to examine how this phenomenon relates to the dominant modernization discourse on women's lives in contemporary Turkey. We analyze women's modes of resistance and conformity to medicalization of birth through qualitative data from 15 focus groups of Turkish women as well as from physicians and midwives. We found out that Turkish women generally submit to medicalized birth, despite unpleasent experiences of hospital birth. We argue that the discourse of modernization and traditional patriarchy both play a role in women's submission to medicalization of birth; and we demonstrate the patterns through which these discourses collaborate in establishing the meaning of childbirth in Turkey.
\end{abstract}

In this study, we examine women's perceptions of childbirth and their experiences of motherhood in the birthing settings in contemporary Turkey. We aim to look into the grounds of surging medicalization of birth by looking into these processes. Whereas current literature on the medicalization of birth relates this phenomenon closely to modernization processes and modernized patriarchal domination, we argue that in the case of Turkey, paradoxically, both modernized and traditional patriarchal processes contribute to the increase in medicalization of birth. On the one hand, modernization discourse in Turkey emphasizes the significance of "modern," "hygienic" motherhood

Received 3 September 2008; accepted 16 January 2009.

The authors would like to thank the IDRC of Canda for a generous research grant, as well as Saime Özcürümez for her meticulous work as a research assistant in data management for this project.

Address correspondence to Dilek Cindoglu, Department of Political Science, Bilkent University, Bilkent, Ankara 06800, Turkey. E-mail: cindoglu@bilkent.edu.tr 
in order to cultivate ideal "seeds" for the nation. On the other hand, traditional patriarchal perception of reproduction tends to regard birthing as "giving birth to a man's seed," taking female body as the secondary component in the experience. We demonstrate how these two perceptions play a mutually reinforcing role in establishing control over the female body and leading to increasingly medicalized birthing settings.

The findings of our research have implications on basically two grounds: (1) The liberating effects of modernization discourse on women need to be further analyzed in the modernizing nations; (2) the intermingling of the "modern" and the "traditional" through women's lives need particular attention in those settings.

In contemporary Turkey, the medicalization of birth has not received the same critical response from women, and alternative birthing methods have not been popular, as they have been in the West. This phenomenon is closely linked with the meaning of birth in contemporary Turkey. This meaning is deeply influenced by patrilineal and patriarchal tradition and reflects the influence of the Turkish modernization discourse on women's daily lives. Therefore, in the context of medicalized birthing in Turkey, the traditional understanding of reproduction and the aspiration of modernization reinforced each other.

Turkey has been experiencing reforms in modernization and Westernization since the nineteenth century, gaining a dramatic pace with the fall of the Ottoman Empire and the foundation of the Turkish Republic in 1923. In the course of establishing the new Republic, Turkish women have been attributed a role as symbols of Turkish modernization (Arat, 1994, 1997; Durakbaşa, 1998). The Kemalist reforms, named after the founder of the Turkish Republic Mustafa Kemal Atatürk (his surname means "father of the Turks"), paved the way for the emancipation of women particularly through the establishment of new legal regulations against traditions that had limited the participation of women in the public sphere. Establishing a modern, Western-faced Republic necessitated emancipating women, particularly from the restraints stemming from Islamic conservatism. With regard to this necessity, revolutionary changes were introduced, such as the new Civil Code in 1926, which banned polygamy and granted women equal rights in divorce and child custody. Women were granted enfranchisement in local elections in 1930 and in national elections in 1934.

Although Atatürk's reforms brought dramatic changes to the status of women, the impact of these reforms on the lives of women in Turkey have been scrutinized from various feminist perspectives. The Turkish modernizers took measures to eliminate physical segregation and to integrate women into the public domain, yet the crucial aspects of gender relations such as sexuality, domestic division of labor, and the sex bias in the public and private domains remained untouched (Erturk, 1991). Kandiyoti (1987) defines this status of women as "emancipated but unliberated." The individual, social, and political rights, which were expected to follow economic inde- 
pendence, never fully materialized (Arat, 1989; Öncü, 1981; Tekeli, 1982). At the same time, working women had to assume a somewhat "Victorian modesty" (Erturk, 1991), or "virtue" (Durakbaşa, 1987) to prove their worthiness of being admitted to public life and to be "good daughters" of the new Republic.

In modernist discourse, women in Turkey have been exposed to new duties in the social sphere, in addition to traditional reproductive duties. Whereas they were endowed with duty and responsibility to the Republic and to the nation, the traditional cornerstones of the oppressive discourse on womanhood in society have remained intact, such as virginity and a woman's chastity, which signifies the honor of her family, kin, husband, and even her son (Cindoglu, Cemrek, Toktas, \& Zencirci, 2008). Paradoxically, while many of the reforms were quite successful in creating women's increased participation in the public realm, a new form of patriarchy that defines itself as modern, progressive, Western, and enlightened was born. Certainly patriarchy and sexism existed in Turkey before 1923, but with modernist reforms, patriarchy spread through arenas of Turkish life that were traditionally women's domain-most notably the healing arts, especially childbearing and childbirth (Cindoğlu \& Moldenhauer, 1998).

In addition, the modernization discourse influenced the domestic sphere by "rationalizing" housework and motherhood. Standards of hygiene in housework and "scientific," "educated" motherhood were particularly emphasized (Durakbaşa, 1998, p. 144). In spite of the emancipating reforms, the Kemalist state still regarded reproduction and childcare as the most important duties for women to perform. In this framework, vocational schools designed particularly for female education (called Girls' Institutions) focused on teaching childcare, nursing, and home economics (Toktaş \& Cindoğlu, 2006). It has been claimed that female education "was promoted mainly with a concern about women's influence over their male offspring, because they were the children's first instructors" (Arat, 1994). Furthermore, the implication of women's education as a means of educating "the nation's offspring" is openly declared in Mustafa Kemal Atatürk's own speeches and writings:

It is the woman who gives a man the earliest words of advice and education, and who exercises on him the initial influence of motherhood. (Atatürk, as quoted in Arat, 1994, p. 60)

Moreover, the traditional ways of motherhood are no longer considered eligible qualifications, and it is underlined that modern motherhood is essential to "cultivate" the nation's offspring:

The education that mothers have to provide their children today is not simple, as it had been in the past. Today's mothers have to attain several high qualities in order to bring up children with the necessary qualities and develop them into active members for life today. Therefore, our 
women are obliged to be more enlightened, more prosperous, and more knowledgeable than our men. If they really want to be the mothers of this nation, this is the way. (Atatürk, as quoted in Arat, 1994, p. 60)

This understanding of motherhood, as subservient to the Turkish nation's aim of development, also sees the child as a "seed" of the nation to be nurtured and "cultivated" first and foremost by the mother.

The perspective of women as "external" contributors to the child's development, in contrast to regarding motherhood as an experience inherent to womanhood, is analyzed insightfully in Delaney's (1991) study, in which she exposes the perceptions of gender and cosmology in Turkish village society. Delaney argues that in terms of reproduction, women's bodies are perceived as "the soil" and men's sperm as "the seed," the initiator of life:

\begin{abstract}
When I suggested to villagers that you couldn't have a child without a woman, they made it clear to me that I had missed the point. Men supply the seed, which encapsulates the essential child. A woman provides only the nurturing context for the fetus. The luxuriant climate of her body is a generalized medium of nurture, like soil, which any woman can provide. It affects the physical growth of the fetus, but in no way affects its autonomy or identity. (Delaney, 1991, p. 32)
\end{abstract}

The "seed" therefore, is the essential element in reproduction; its role is hierarchically superior to that of the "soil":

Seed and soil, seemingly such innocent images, condense powerful meanings: although they appear to go together naturally, they are categorically different, hierarchically ordered and differently valued. With seed, men appear to provide the creative spark of life, the essential identity of a child; while women, like soil, contribute the nurturant material that sustains it. (Delaney, 1991, p. 8).

Furthermore, the perception of the woman's body as "the carrier of the seed" rather than an essential element of reproduction has profound implications for women's sense of control over their own bodies. The husband, the provider of the seed, claims the control over the woman's body through the means of "protecting his seed" and ensuring that the child is from his own seed. This control lies at the heart of honor codes, and the man's honor “depends on his ability to control 'his' woman” (Delaney, 1991, p. 39). Moreover, the woman's body is subject to expectations from her extended family and from society.

King (2008) relates this perception of reproduction to the concept of "patrilineal sovereignty." Accordingly, she argues that in circum-Mediterranean, Middle Eastern, Central Asian, and South Asian cultures-as women are perceived to be the carriers of the male seed, the struggle to maintain patrilineal 
sovereignty, particularly reproductive sovereignty, necessitates controlling women's sexuality. In King's account, this lies behind the subjugation of women and the concept of namus: honor, or, precisely, sexual honor: "If a woman is understood to merely nurture seed, not co-generate it, then she can only be used in the procreative process-possibly by the wrong genitor. She must therefore be cloistered to reduce this possibility" (King, 2008, p. 326). On the other hand, Yuval-Davis and Stoetzler emphasize that women "embody and cross collectivity boundaries and territorial borders" (2002, p. 329). Therefore, the authors attribute special significance to how women imagine boundaries and the specific roles they can play in peace activism.

Along a similar line, Delaney (1995) shows how the symbols of the Turkish nation powerfully reflect conceptions related to reproduction. Acknowledging that "the very conception of the nation and nationalism is itself an inherently gendered discourse" (Delaney, 1995, p. 191), she points out the expressions of this gendered discourse in metaphors such as "motherland" (anavatan) and "father state" (devlet baba) and in the very name of Atatürk, which means "father Turk." She further argues that the utilization of the conception of "motherland" and its implications related to namus appeal to Anatolian peasants. The support of the peasantry in the War of Independence against allied powers, who divided and shared Anatolia after World War I, can be attributed to those analogies:

\begin{abstract}
Peasants did not have to understand the idea of a nation-state to be motivated to protect their own threatened soil if it was understood as their mother who was being raped and sold into captivity. Once their sense of honor was called upon, they rose up against the intruders and ejected them from their soil. (Delaney, 1995, p. 186)
\end{abstract}

In Delaney's account, this rhetorical strategy also was used to lay the conceptual ground of the new nation-state. This framework helps us understand the reasons why emancipating women has not corresponded to liberating them from patriarchal bonds in the case of Turkey. Women were regarded as the symbols of the land and boundaries of the nation, as well as agents that would nurture and reproduce the seeds of the nation. Indeed, the symbolic significance attributed to motherhood and the concern over the reproductive sovereignty of a nation are not uniquely confined to Turkey's nation-building process (Kandiyoti, 1991). For example, Halkias (2003) examines how reproduction and national identity relate to each other in the context of Greece, and argues that nationalist discourses succeeded in making women internalize the reproductive policy of "having at least one child." Still, the impact of seemingly contradictory discourses referring to modern values, while at the same time maintaining the traditional patriarchal ties, has given way to peculiar practices that reflect the combination of "the modern" and "the traditional" in the everyday lives of women in Turkey. 
In some contexts, contradictory discourses do not necessarily contradict but may well lead to new everyday practices that reflect the hybridity and blurred lines between the traditional and the modern. The dramatically medicalized birthing setting in Turkey is one such context, in which the modern notion of medicalization coincides and collaborates with the traditional patriarchal conception of reproduction, leading to an unintended consequence.

In order to illustrate how the modern notion of medicalization and the patriarchal conception of reproduction reinforce each other through the birthing experiences of women in Turkey, we first investigate the discussion on the global phenomenon of medicalization of birth and its potential implications, in terms of establishing control over women's bodies.

\title{
MEDICALIZATION OF BIRTH
}

The term "medicalization" refers to subordinating certain practices, experiences, and behaviors to the authority of medicine. Kohler Riessman (2003) states that two interrelated processes are inherent to the definition of medicalization:

\begin{abstract}
First, certain behaviours or conditions are given medical meaning-that is, defined in terms of health and illness. Second, medical practice becomes a vehicle for eliminating or controlling problematic experiences that are defined as deviant for the purpose of securing adherence to social norms. (p. 47)
\end{abstract}

In this framework, the term medicalization is loaded with implications of "control" over bodies and experiences. Foucault's work provides an understanding of how control and discipline of bodies are embedded within the process of modernization (Foucault 1973, 1979). He argues that modern institutions such as hospitals, the army, and schools aim to produce "docile bodies" in order to transform the body into a more efficient, utilizable unit: "The human body was entering a machinery of power that explores it, breaks it down and rearranges it. ... Thus, discipline produces subjected and practiced bodies, 'docile' bodies" (Foucault, 1979, p. 138). Bartky criticizes Foucault for overlooking the gender dimension and argues that it is essential to refer to the modernization of patriarchal domination, while accounting for modern disciplinary practices (2003, p. 28).

Studying the medicalization of birth provides the opportunity to trace the patterns of modernized patriarchal domination upon women's bodies and experiences. The literature on gender relations in medicine discusses how male domination in medicine affects the health care women receive (Corea, 1985; Dan \& Lewis, 1992; Fisher, 1986). It is argued that unfair treatments and unequal power relations are even more evident around the processes 
specific to women, such as birth. Toward the eighteenth century, the female body became a medical object; since that time, pregnancy, contraception, abortion, and menopause all have become defined as medical issues, subject to medical treatment and control. Women's reproductive lives have become increasingly medicalized during the twentieth century in the Western world (Greil, 1991). In this process, "social birth" was replaced by medical birth and home births were replaced by hospital births.

It is argued that the medicalization of pregnancy and birth is closely connected to patriarchy, because defining pregnancy as abnormal and pathological reflects the perception that women are, by nature, victims of their own reproductive systems. The medical discourse that regards pregnancy as an illness limits and violates women's autonomy over their own bodies (Cahill, 2001, p. 334). Indeed, the medicalization of birth has not come about without women's contribution. It is argued that in the Western world, women have given consent to the medicalization of childbirth since the turn of the century "to free themselves from the control that biological processes have had over their lives," "which paradoxically led to the biomedical control of their own experiences (Kohler Riessman, 2003, p. 59).

According to Kohler Riessman, one of the reasons for the increasing medicalization of pregnancy and birth is that obstetricians have been struggling to establish a respectable image for their field since the first decade of the twentieth century. In order to do that, "they argued that normal pregnancy and parturition were an exception rather than the rule" (Kohler Riessman, 2003, p. 51). Besides, it also is argued that women settle for medicalization because of their concern for a safe birth. According to this argument, women are convinced to be passive and dependent on the medical profession in order to achieve safety in the process of giving birth (Cahill, 2001). This argument is supported by the suggestion that the medical discourse has constructed a "risky" perception of childbirth, therefore legitimizing excessive medical intrusion into the event (Zadoroznyj, 1999, p. 268). Furthermore, according to Lazarus, women are also pressured by the fear that they may be blamed for complexities that could arise in birth if they do not strictly follow the doctors' advice (as cited in Liamputtong, 2005).

Whereas the medicalization of birth frequently is criticized because it causes a loss of women's authority and autonomy over their own bodies, Davis-Floyd's (1994) study reveals that American middle-class women see medicalized birth as a means of control and empowerment over their birth experiences, rather than as a loss of autonomy. This perspective results from these women's determination to utilize the highest medical technology in their births. For example, they want to be able to opt for a cesarean section, because this makes them feel that they are "in control." To the contrary, Parry (2008) argues that Canadian women empower themselves by resisting medicalization of birth through use of midwifery. 
Indeed, the perspective that regards women as actors rather than passive victims in medicalized birthing processes contributes to a more thorough understanding of the rise in medicalization. In her study in which she questions the reasons for the high cesarean section birth rate in Brazil, Béhague (2002) defies arguments that attribute the high rate to factors external to women, such as economic incentives of physicians. She argues that Brazilian women are actively strategizing; for example they opt for cesarean sections in order to avoid the normal birth experience in public-sector hospitals, which can be unpleasant. Furthermore, having given birth by a cesarean section is a matter of social status for women and leads them to feel more "cared for" (Béhague, 2002, p. 485).

The literature on the medicalization of birth takes a critical stance on this phenomenon by looking into the power relations that women find themselves in during medicalized childbirth experiences, especially in the last 30 years (Crossley, 2007). Although the medicalization of birth is on a striking increase in contemporary Turkey, this phenomenon has not been studied from such a critical perspective. An overwhelming majority of the studies conducted on women and medicine in Turkey has been from the tradition of sociology in medicine; that is, they deal with the socioepidemiological aspects, such as infant mortality rates, women's insufficient nutrition, or perinatal or maternal mortality and fertility.

The rise in the medicalization of birth in Turkey is clearly observed in the increase in hospitalization of births and the upward surge in cesarean section deliveries. Ministry of Health data demonstrate that there has been a steady increase in the number of hospital births: Whereas in 2001, there were 531,553 births in the hospitals of the Ministry, this number rose to 706,000 births in 2006. Briefly, in 2003, $79.8 \%$ of all births took place in the hospital setting (Hacettepe University Institution of Population Studies, 2003) and $21.2 \%$ of these births were in cesarean section form, far beyond the standards of the World Health Organization, which suggests that cesarean section birth rates should not exceed 15\%. Moreover, in the period between 1998 through 2007, there was a significant increase in first-birth cesarean sections. See Table 1. According to the response of Ministry of Health to our inquiry, in 2006, 288,000 of 706,000 babies delivered in hospitals of the Ministry have been delivered by cesarean sections, which makes a percentage of 40.7 . In

TABLE 1 The Ratio of C-Section Births Over Time

\begin{tabular}{lccc}
\hline Year & 1998 & 2003 & $2006-2007$ \\
\hline $\begin{array}{l}\text { Percent of c-section births in Ministry } \\
\text { of Health hospitals }\end{array}$ & 13.9 & 21.2 & 36.7 \\
\hline
\end{tabular}

Sources: For 1998 and 2003 data, see Hacettepe University Institute of Population Studies (1998, 2003), Turkey Demographic and Health Survey. The average of c-section rates in 2006 and 2007 has been derived from Turkish Ministry of Health upon request by the authors. 
$2007,251,000$ of 766,000 babies have been delivered by cesarean section; hence there is a percentage of 32.7. Therefore, in 2006 and 2007, an average of $36.7 \%$ of births in Ministry of Health hospitals were conducted by cesarean sections.

In Tatar and colleagues' study (2000), conducted in a teaching hospital in Ankara, Turkey, women who delivered babies through cesarean section births expressed dissatisfaction with the birthing experience. The authors argue that in order to understand the scope of the problem behind the surge in cesarean section deliveries, a sociological perspective and qualitative studies that handle the issue from the patient's perspective are needed (Tatar et al., 2000). Indeed, our study is an attempt in this direction. Clearly, the process of pregnancy and birth are increasingly perceived as a medical process in Turkey. The social dynamics behind this increase, however, have not been explored. Our main objective is to understand the intricacies of the Turkish context that lead to such an overwhelming trend of medicalizing birth. In order to do that, we look into the perceptions of women, physicians, and midwives regarding the childbirth experience.

\section{METHOD}

In this article- $-\mathrm{a}$ by-product of a study conducted in 1996, sponsored by the International Development and Research Center (IDRC) of Canada-we explore gender and power issues in the birthing settings in contemporary metropolitan Turkey, in the cities of Ankara, Istanbul, and Izmir. The research findings were published as a report for the IDRC of Canada. In this study, however, we analyze the data within a new framework. The perceptions of female "patients," physicians, and midwives related to childbirth have gained new relevance in today's birthing context, which has become strikingly medicalized. As demonstrated in Table 1, cesarean section births have been on a steady rise since the 1990s. The data of this study provides insight into the social dynamics behind the tendency toward medicalizing the birthing experience among women in Turkey.

In the course of this exploratory research, 15 focus group interviews were conducted. The use of focus groups is an appropriate method for obtaining the participants' perspectives and experiences (Kruger, 1988; Morgan, 1988, 1993; Stewart \& Shamdasani, 1990) as well as providing the opportunity to understand the common dynamics among these experiences (Wilkinson, 2004). The focus groups in this study consisted of physicians, nurse midwives, and women who visited health care units for problems related to reproductive functions. A majority of these women had experienced childbirth. The participant women were asked to tell their birth experiences, the factors that affected their decisions pertaining to the birth settings, and their perceptions of their birth experiences. In the focus group interviews 
conducted with physicians and midwives, the participants' social interactions with the health care receivers were explored, as well as their insights into the patterns of attitudes and experiences related to the birthing setting. Focus groups were conducted in the three most populated cities in Turkey: Istanbul, Izmir, and Ankara. These cities were selected due to their different regional settings and because they receive immigrants from all over the country.

Nine of the 15 focus groups were conducted with women who had ever visited health care units for problems related to reproductive functions. In the design of these groups, the education factor was controlled for: Three groups were conducted with illiterate women, three groups with women who had 5 to 11 years of education, and three groups with more highly educated women. Four focus groups were conducted with physicians who served the reproductive health care of women in any capacity. One focus group consisted of state-employed midwives and one of midwives employed in medical school.

\section{THE STUDY}

We analyze the data retrieved from women with recent birth experiences, from physicians, and from midwives with regard to these points: (1) women's perceptions related to "the hospital" and a medicalized birth experience, including cesarean sections; (2) women's perception of medical personnel, particularly physicians; (3) the perceptions of physicians and midwives of medicalized birth; and (4) the relations of physicians and midwives with patients.

\section{WOMEN'S PERSPECTIVE}

\section{The Hospital: Ease or Disappointment?}

Carol Delaney (1991) tells the story of a pregnant woman from a village in inner Anatolia, in which she conducted her ethnographic study. This woman wanted to give birth in a hospital in the city, different from other women in her village, in the hope of receiving respect, special attention, and kind manners as well as better medical care:

What began as an exciting journey into modernity ended with bitter disappointment. She had expected that educated doctors would treat women with more respect than they generally receive in the village, but her illusions were shattered ... Doctors and nurses seemed to consider them almost subhuman, like animals, unable to speak or think. (Delaney, 1991, p. 62) 
The humiliation and disappointment with the "modern" birth setting that Delaney mentions is not an exceptional phenomenon, and many women in our study expressed similar experiences. Not only theoretically, but through the women's eyes and words, it is possible to witness the "total institutional" nature of the hospitals, where one is treated as a "case" and the procedures strip you of your identity, in Goffman's (1961) words. Birthing, both in terms of traditional and modern values, is expected to provide status to women. This unwelcoming or even degrading treatment opposes the women's expectations and creates a cognitive dissonance and unhappiness. One of the participants who gave birth in a public hospital expressed her disappointment with the treatment she faced while she was giving birth:

Everyone in hospital is a stranger. We fear doctors and nurses. When you scream they scold you: "Why are you screaming?" A life is coming out of another life! If there was a maternity nurse, I would feel more comfortable. I'm not comfortable in hospitals. They don't value you at all as a human being. It's not as it seems from outside.

Our findings indicate a common pattern of discontent with the physical environment in state hospitals, in which women seem to deliver their babies with little attention from physicians. Participants explicitly voiced their frustration with giving birth in the delivery rooms of public hospitals, where many women were going through labor at the same time:

They took me to the delivery room. There were five people having babies at the same time. What I saw really ruined me! But I had no choice. I had to deliver, I was there. They prepared me, gave me injections, and there I was waiting. I was lonely.

Similarly, many other interviewees who gave birth in public hospitals complained about the labor rooms crammed with many women trying to deliver their babies. There are quite striking experiences, such as two women trying to give birth on the same bed and 30 women laboring in the same room with only one physician attending to all women at the same time. The fact that almost all focus group participants who gave birth in a public hospital voiced similar discontent leads to serious considerations about the quality of the medical care in hospital birthing settings. Although these women's experiences display a problem of inadequate medical care, many participants considered hospital birth as the "norm":

Now it does not work in the village. There are so many illnesses. It is obligatory to go to a hospital. You should give birth in urban environment. 
Some women emphasized the hardships of giving birth in rural areas as opposed to the urban births, where both the mother and the baby are seemingly better off in terms of "care" because, in the village settings, the gender role responsibilities continue even right after childbirth. On the other hand, hospitals make the birth a legitimate time for getting rest and abstaining from gender-role responsibilities:

In the village, birth is easy but afterwards there is no care. The bride does not lie, does not sit, does not eat, she works and does all the work. Whether or not the child cries does not matter. One of my children died after 8 months. I could not breastfeed him enough. They do not let you breastfeed since there is so much work to do.

Some women perceived birth as a "risky" process as opposed to a normal life occurrence. In order to avoid any possible health "risk," they prefer hospital births. Our findings suggest that not only home birth but even normal (vaginal) birth has started to be regarded as "risky" by some women, especially those who have given or tend to give birth by cesarean section:

I learned that c-section births are better for baby's brain. Besides, its head comes out in better shape. They say that during normal birth there is pressure. The baby may lack oxygen. So it is risky.

Another participant related this risk to the perception of ambiguity within the birthing process. According to this view, a cesarean section birth is safer because it is more predictable:

I liked c-section, actually. In normal birth, you don't know what will happen, when it will happen. You worry more. Especially for the baby's health.

\section{Relations With the Physicians}

Participant patients' narratives about their relations with physicians during pregnancy and childbirth are laden with connotations of shame, as well as a combination of respect and fear, especially in public hospitals. Feelings of shame and discomfort are voiced, particularly about experiences with male physicians. The narratives of patients stress that not only the physicians' gender, but also their insensitive behaviors, words, and jokes, sometimes add to the perceived discomfort. The importance of respect for privacy and dignity has been mentioned over and over during the focus groups: 
It was at the Zeynep Kamil Hospital; medically, it is a very good one, but the doctors are shouting at you, and you are shouting at them. They ask, "Did you ask me when you were doing it?" How tasteless!

In the narratives of women who participated in our research, it is possible to observe that in public hospitals, being yelled at or lashed by a physician is almost common, even during the process of giving birth:

I delivered in the SSK (social security institution) hospital. I am there in labor, in bed, in pain, and two doctors are sitting there as if nothing is happening. "Woman, do not shout!" he says. "If you scream, I won't examine you." The baby is coming. How can I possibly not scream!

Although most women complained about the degrading attitudes of physicians, at the same time they emphasized the importance of physician existence in the birth settings as a source of trust, even though the public hospital births are commonly described as lonely, frightening, and unattended experiences:

Nevertheless, there is a trust to the doctor there. Indeed, we suffer all by ourselves. There is no one that helps. Baby comes. I mean, there is nobody that helps. Again we give birth to the child all by ourselves. Still, there is trust.

Whereas the experiences in public hospitals demonstrate neglecting and degrading attitudes of the physicians, almost all women who have given birth in these private institutions express birth settings in private hospitals as "totally different":

I have been to public hospital before. The doctor there shouted at me and ordered me: "Open up your legs." Nurses treat you so terribly that they are probably gentler to animals, but then I went to Güven and Bayındır hospitals (private institutions). The treatment I received there was totally different.

\section{PHYSICIANS' AND MIDWIVES' PERSPECTIVES}

\section{The Hospital and Medicalized Birth}

The focus group interviews with the physicians yielded a clear pattern of a perception of childbirth as extremely "risky." This perception leads almost all physicians to favor hospital births and to emphasize the dangers related to home births: 
Birth is a risky event. The baby can die inside you. Your womb can leap out onto your leg. It happens once in a thousand, but what if you are the one in a thousand?

Many physicians regarded cesarean sections as healthier, or "less problematic" than vaginal births, for cesarean sections turn childbirth into a "predictable" and controllable phenomenon:

I prefer to deliver babies by c-section. It is much better. The mother doesn't have to struggle; the baby doesn't have to struggle. You just take the baby out; that is all. You deliver by appointment. As a doctor, you do not have to try to make critical decisions about the patient's life, as in the case of normal birth.

Two other physicians were strikingly explicit in explaining their practical motives in choosing cesarean sections. They mentioned that cesarean sections made birth not only predictable but also profitable in terms of time and money:

One normal birth in public hospital means losing the time you could spare to eight patients in the private practice. You lose money. In addition, you have to be alert at nights. Why wait? The baby will be delivered either way. Of course, I immediately say "yes" to whoever wants a c-section.

You leave your children at home; you leave your sleep. You deliver in sweat, after working for 10 hours. Then what happens? Does the patient thank you? No. She says, "I suffered a lot," "you made me scream out of pain," etc. But in c-section, no pain, no suffering, no waiting. I am not even mentioning the money.

\section{Relations With the Patients}

The narratives of physicians working at public hospitals generally did not contest the unpleasant experiences that women express about their relation to the physicians in birthing settings. For example, one physician said that he did not feel the responsibility to respond when a patient in labor screams:

There are such patients that they see the hospital for the first time in their lives. Probably she has come from her village or lives in ghettos of Istanbul. She feels like an alien in the civilized hospital. That is why she screams, because of her fear. 
Another physician, who equally disliked screaming women in labor, claimed that screaming is not natural but cultural:

Foreign women never scream, even when giving vaginal birth. They bite on their pillows; they find something to squeeze, etc. They do not scream.

One physician argued that mean treatment, even hitting a patient in labor, is sometimes "necessary":

The nurse was applying pressure over the woman's abdomen to bring out the baby. The woman started to scream like an ambulance. The nurse hit the woman. Now if you ask that woman, she would say, "the hospital is bad; they beat me," but we had to bring out the baby as soon as possible. Otherwise, its brain could be damaged.

The findings of our focus group interviews with the physicians point to a clear pattern of hierarchical control and authority over patients, which they legitimize by medical knowledge and expertise:

A pregnant woman has nothing to give me, but we have everything to give her. We have knowledge, method, and capability. Therefore, we have to lead.

One physician expressed a paradoxical attitude in this regard: On the one hand, he argued that such control is necessary and "good for the patient"; on the other hand, he admitted that he did not behave in that way to certain patients, such as those with higher education:

I especially like patients who completely submit themselves to medicine, but, of course, there are other categories of patients, like the educated ones. As the patient's social level goes down, I have more say on the patient. I have more confidence.

Whereas physicians were generally in agreement about their expectation of subordination to their medical expertise, the issue was argued in midwives' focus groups. One midwife acknowledged the fact that some women are slapped on the legs while giving birth:

Some women are really very ignorant. If they could breathe well, push the baby properly, if they did not scream that much, they would not be slapped, but, of course, we should not use our knowledge to insult them. Maybe some of us are caught in a superiority complex. 


\section{Concern Over "The Seed"}

As demonstrated in the sections above, most women's experiences related to hospital—especially public hospital—births were far from pleasant. Still, the common pattern in women's narratives reveals that any alternative birthing setting is unthinkable. Obviously, the common conception of birth as a risky process is one reason. Many interviewees, however, seemed more concerned with the baby's health than with their own health or well-being, even though a pregnant woman's well-being directly affects her baby:

It is impossible for me to think about giving birth at home, because the baby is much more important than I am. I mean, I don't think about my health or how I am treated as long as the baby comes out well.

Another woman openly expressed how she related the perception of pregnancy as a disease and the perception of fetus as "external" to her own body:

I never had special feelings about pregnancy. I saw my pregnancy as a disease. I know that giving birth is a nice thing, but I was not sensitive. Rather, I wanted someone to care about my pregnancy. For example, I was very surprised while listening to you (talking to another focus group participant). You see the fetus as a part of yourself. This will probably cause problems in your relation with the child in the future.

This participant from a relatively less well off and less educated background also regarded her pregnancy as a reason to expect special care from other people. Bourqie, through the findings of his research on Moroccan women (1990), argues that women use their reproductive function as a token to negotiate their status and to create occasions to express their desires. The "utilization" of pregnancy as such connotes that the woman is restrained from expressing her desires unless she is pregnant.

Actually, it is not only up to women to choose a birth setting. A participant made it clear that although she wanted to give birth at home, she complied with her husband's preference to take her to the hospital:

I suffered a lot. Maybe, at home, it would have been better. My husband did not let that. I thought it would be more comfortable at home. I insisted a lot, but he did not want. I said we might arrange a midwife to come home, but he did not want. So, I delivered at the hospital.

Moreover, in women's narratives, it was revealed that the husbands' preferences influence not only the choice of birth setting but all issues related to reproduction, such as abortion and sterilization. An educated, 
middle-class interviewee told the story of her cousin, who is from a more humble background:

My cousin had two difficult births, and also had some miscarriages. Her womb was damaged; she did not want any other babies. They asked her if she wanted to be sterilized. She was worried that her husband may want other babies, and could divorce her to have new children. And the husband did not allow sterilization. A few years later, she got pregnant again and had to have an abortion. In a few days, while she is having a bath, suddenly she sees streams of blood running. She was so indifferent to her own body that I was shocked! I took her to the hospital and she had to have the second abortion in a week. Her womb was badly damaged.

Men's sensitivity related to the "capability" of having children is a strong motive, leading to the tendency of neglecting the mother's health for the sake of having children, as in the case above. This attitude leads to a loss of women's control over their own bodies and reproductive functions. More importantly, many physician participants of the focus groups also complied with men's domination over their wives' reproductive functions, sometimes at the cost of violating doctor-patient confidentiality. A doctor explained that in cases of complication related to pregnancy, many women feel the urge to keep secret from their husband any complications that might be blamed on them. Apparently, he did not like to keep his patients' "secrets":

- For example, there is an emergency and we are examining a woman. Women sometimes say, "Please do not let my husband learn this." We say, "No." The husband has to know. We cannot accept otherwise. Something may come up and he may find out. Then he will cause trouble.

- But he can't do anything legally.

- Alright, but we still want him to know.

Delaney (1991) states that in Turkish village society, "A man's power and authority, in short, his value as a man, derives from his power to generate life" (p. 39). The "sensitivity" of men related to reproduction is reflected in their perceived need to dominate women's reproductive functions. This sensitivity is even more visible when men's own reproductive capabilities are at stake. One physician clarified this phenomenon, which is neither surprising nor rare in the Turkish context:

Even very educated and well-off people make it a matter of pride. Men always interpret it this way. If the result is bad, he accepts that he cannot perform his manly duty, he has this hang-up all the time. I had a patient; his wife was fertile. She had all kinds of tests and procedures. The man is the one with the problem. As soon as they came to me, the man said, "I 
have had treatment; there is no problem with me." He would not show his test results to me. I learned from his relatives that his condition was not sufficient despite the treatment he went through.

\section{DISCUSSION AND CONCLUSION}

Having conducted this study, we learned that women in Turkey increasingly submit to medicalized birth, although the birth stories in public hospitals mostly uncover unpleasant experiences. Even though women voice their discontent with their birth experiences in hospitals, they do not seem to consider or even desire the prospect of an alternative birth setting, except to choose private institutions, which is possible for only women of better economic means. Rather, they tend to regard hospital births as an inevitable aspect of modern life. It is important to seek the root causes of this paradoxical situation, for these causes will give us the insight to the reasons of the ever-increasing medicalization of birth and excessive cesarean sections.

In this section, we discuss three main themes that appear in the narratives derived from focus group discussions: (1) the risky perception of birth; (2) expert language that incorporates modern medical authority with a patriarchal regard for woman's sexuality; and (3) the perception of the baby as a product of man rather than woman, in parallel to the conception of the baby as the "seed."

\section{Risky Birth vs. Predictable Birth}

Depending on the findings of our research, we argue that there is a tendency among women in Turkey to settle for medicalization, due to the concern for a safe birth. Although many women tell of the times their mothers gave birth at home in the presence of a midwife, they seem convinced that there are too many risks in the childbirth process. These risks can be overcome only in a hospital, which provides a sterile medium where doctors constantly watch patients. Therefore, although, in public hospitals, a sterile environment is of little concern, and doctors do not attend all the time, a hospital is considered a "must."

Zadoroznyj (1999) argues that birth is constructed as a "risky" perception by medical discourse, which tries to legitimize excessive medical intrusion. Considering the narratives of physicians, it seems possible to argue that physicians really think of birth as a risky event with hundreds of probable complications. Moreover, it is observable that physicians try to avoid any kinds of ambiguities, which leads some of them to be skeptical even about vaginal birth. The physicians that prefer to deliver by cesarean sections have two types of concerns. First, there are the practical and pragmatic concerns: 
Vaginal birth takes a long time, the doctor may have to spend all night trying to deliver, it is painful for the laboring woman, and the doctor earns less money in the end. Second, there are concerns related to the "unpredictability" of vaginal childbirth. Especially younger and less experienced physicians do not like to make decisions in ambiguous situations; on the other hand when a cesarean section already has been decided upon, the doctor makes the appointment and takes the baby out. Hence, ambiguous situations are avoided. Both types of concerns indicate a similar motive: to "clean" childbirth from the sweat, tears, and unpredictable aspects of the experience and turn it into a predictable, sterile, surgical process that also is time efficient.

Whereas increased medicalization makes childbirth a more predictable and thus controllable process for birthing women and physicians, research suggests two different dynamics that may play a role in women's submission to excessive medicalization. First, as Lazarus (cited in Liamputtong, 2005) suggests, women fear to be blamed for complications in childbirth. In our study, some women, especially those from less-educated focus groups, expressed the fear that complications in the birthing process might be blamed on them, especially by their husbands, so they preferred to have an institution to take the "blame." Second, one motivation to opt for hospital birth, especially among rural women who lived in extended families, was the will to "get some rest" after birth. These women complained that soon after home birth they were expected to get up and proceed with housework duties. Being hospitalized gave them some space to rest, not to mention status and the feeling of being cared for.

\section{Expert Language}

The narratives in both the women's and physicians' focus groups follow a clear pattern of emphasizing the hierarchical and authoritarian nature of the physicians' relations to patients. It is not only a relationship of medical authority, but it also is a relationship in which female sexuality is degraded or women are treated harshly or neglected, even during labor.

Women who consume reproductive health services obviously do not like physicians' attitudes, but they usually accept them, either out of respect for medical authority or simply out of fear of authority. Interestingly, the feeling of "obligation to the hospital setting" seems to be a factor in putting up with an attitude that is degrading in many respects. In women's narratives, the hospital appears as an unquestionable necessity that accompanies the package of modernity and "modern life." The image of a modern urban hospital full of technical equipment and expert staff cannot compete with any other alternative in the age of modernity. This image is strengthened by counterimages of home births, especially in rural settings, which reflect 
primitive, dirty, and frightening pictures of "being backward" and failing to keep up with modernity. The Turkish modernization discourse has had a powerful influence on the daily lives of women and on their domestic practices, with the aim of transforming the domestic realm to keep up with the modern life that the Turkish nation embraced. The findings of this study confirm the influence that the modernization process has had on women's daily lives, because it is possible to observe that although most women complain about their physicians' insensitive behavior and the alienating atmosphere in the hospitals, their experiences reflect a mixed sense of fear, respect, and submission in the face of modern medical authorities. As Delaney (1991) rightly claims, giving birth in the hospital corresponds to a "journey to modernity," especially for women of rural backgrounds.

On the other hand, physicians in general do not deny that they display quite "authoritarian" attitudes in their relations with patients. Commonly, they legitimize their attitude with their medical knowledge and with the argument that what they are doing is for the well-being of the patient. They seem to change their attitude, however, according to the socioeconomic background of patients. Whether the patient is educated and whether she is from a rural or an urban background seems quite decisive. While physicians and midwives defend their attitudes, they usually make loaded references to the concepts of "modern" and "traditional." Being uneducated and coming from a village seems to correspond to being "traditional" or "backward," not knowing how to behave in a modern building and how to talk to physicians, displaying uncontrolled and undisciplined behavior, such as screaming unnecessarily during birth. These are presented as justifications to harsh or neglectful attitudes. The discourse of the physicians could be explained by borrowing Foucault's concept of the "docile body"; in particular, "bodies" from rural areas have not yet been disciplined and rearranged to fit into the institution of modern medicine.

Interestingly, this strong reference to modernization does not seem to eradicate the scornful regard of female sexuality. This regard is evident in many experiences voiced by women, such as degrading jokes about sex and pregnancy, slapping the legs during labor, and so on. This demonstrates that the disciplinary process of modernization carries new prospects for patriarchal domination to reproduce itself in a modernized form, as Bartky (2003) argues.

\section{Perception of the Baby as "The Seed"}

The last pattern we observed within the narratives is the perception of the baby as belonging to the father rather than to the mother. This has multiple connotations, not only related to childbirth but also to the perception of a woman's body as the soil through which others' wishes are fulfilled and 
patrilineal descent is preserved along with "honor," as revealed in Delaney (1991, 1995) and King (2008).

What kind of an impact does the perception of the baby as the "seed" of the father have on the medicalization of birth in Turkey? Throughout the findings of the research, we observed a pattern such that women tend to regard the female body as the "second actor" in the birthing experience. Women are concerned with properly carrying and giving birth to "the seed," rather than seeking a better and healthier birthing experience, as if their own well-being did not directly affect the baby. We observed this pattern of thinking mostly among illiterate women or women with some years of education, and especially those living with their extended families. Hospital births provide a safety net mechanism for them to negotiate any possible wrongdoing in the birthing process. Should something go wrong with the "seed"/baby, they have the medical institution to blame. With similar motivations, most women do not challenge the demands of the father-to-be about the birthing process, which places masculine control over birth. Moreover, it is possible to observe such control and dominance in other decisions about women's bodies that affect their fertility. Although it may be considered normal that both members of the couple should make decisions about such options as abortion and sterilization, in the case of Turkey it is more likely to be the man who has the last word on such decisions. This general tendency is a repercussion of the perception of the woman's body as "the soil" that will cultivate the man's seed.

\section{REFERENCES}

Arat, Y. (1989). The patriarchal paradox: Women politicians in Turkey. Cranbury, NJ: Associated University Presses.

Arat, Y. (1997). The project of modernity and women in Turkey. In S. Bozdoğan \& R. Kasaba (Eds.), Rethinking modernity and national identity in Turkey (pp. 95-111). Seattle: University of Washington Press.

Arat, Z. (1994). Turkish women and the republican reconstruction of tradition. In M. Göçek \& S. Balaghi (Eds.), Reconstructing gender in the Middle East (pp. 57-78). New York: Columbia University Press.

Bartky, S. L. (2003). Foucault, femininity, and the modernization of patriarchal power. In R. Weitz (Ed.), The politics of women's bodies: Sexuality, appearance and behaviour (pp. 25-45). New York and Oxford: Oxford University Press.

Béhague, D. P. (2002). Beyond the simple economics of cesarean section birthing: Women's resistance to social inequality. Culture, Medicine and Psychiatry, 26, 473-507.

Bourqie, R. (1990, December). The woman's body: Strategy of illness in Morocco. Unpublished paper presented at the workshop Towards More Efficiency in Women's Health and Child Survival Strategies-Combining Knowledge and Practical Solutions, Cairo. 
Cahill, H. (2001). Male appropriation and medicalization of childbirth: A historical analysis. Journal of Advanced Nursing, 33, 334-342.

Cindoglu, D., Cemrek, M., Toktas, S., \& Zencirci, G. (2008). The family in Turkey: The battleground of the modern and the traditional. In C. Hennon \& S. M. Wilson (Eds.), Families in a global context (pp. 235-265). New York: Routledge.

Cindoğlu, D., \& Moldenhauer, J. A. (1998, June). Herstory of modernization: Reflections on the birthing settings of modern Turkey. Paper presented at The Ninth International Congress on Women's Health Issues, Alexandria University, Alexandria, Egypt.

Corea, G. (1985). The bidden malpractice: How American medicine mistreats women. New York: Colophon Books/Harper \& Row Publishers.

Crossley, M. L. (2007). Childbirth, complications and the illusion of 'choice': A case study. Feminism \& Psychology, 17, 543-563.

Dan, A. J. \& Lewis, L. (1992). Menstrual health in women's lives. Urbana and Chicago: University of Illinois Press.

Davis-Floyd, R. E. (1994). The technocratic body: American childbirth as cultural expression. Social Science and Medicine, 38, 1125-1140.

Delaney, C. (1991). The seed and the soil: Gender and cosmology in Turkish village society. Berkeley, CA: University of California Press.

Delaney, C. (1995). Father state, motherland, and the birth of Modern Turkey. In S. Yanagisako \& C. Delaney (Eds.), Naturalizing power: Essays in feminist cultural analysis (pp. 177-199). New York and London: Routledge.

Durakbaşa, A. (1987). The formation of Kemalist female identity. Unpublished master's thesis. Istanbul: Bogazici University.

Durakbaşa, A. (1998). Kemalism as identity politics in Turkey. In Z. Arat (Ed.), Deconstructing images of "the Turkish woman" (pp. 139-155). New York: St. Martin's Press.

Erturk, Y. (1991). Convergence and divergence in the status of Muslim women: The cases of Turkey and Saudi Arabia. International Sociology, 6, 307-320.

Fisher, S. (1986). In the patient's best interest: Women and the politics of medical decisions (2nd ed.). New Brunswick, NJ: Rutgers University Press.

Foucault, M. (1973). The birth of the clinic: An archeology of medical perception. New York: Pantheon.

Foucault, M. (1979). Discipline and punish: The birth of the prison. New York: Vintage.

Goffman, E. (1961). Asylums: Essays on the social situation of mental patients and other inmates. New York: Doubleday Anchor.

Greil, A. L. (1991). Not yet pregnant: Infertile couples in contemporary America. New Brunswick, NJ: Rutgers University Press.

Hacettepe University Institute of Population Studies. (1998). Turkey demographic and bealth survey, 1998. Ankara, Turkey: Author and Macro International, Inc.

Hacettepe University Institute of Population Studies. (2003). Turkey demographic and health survey, 2003. Ankara, Turkey: Author, Ministry of Health General Directorate of Mother and Child Health and Family Planning, State Planning Organization and European Union.

Halkias, A (2003). Money, God and race: The politics of reproduction and the nation in modern Greece. European Journal of Women's Studies, 10, 211-232. 
Kandiyoti, D. (1987). Emancipated but unliberated: Reflections on the Turkish case. Feminist Studies, 13, 317-338.

Kandiyoti, D. (1991). Identity and its discontents: Women and the nation. Millennium: Journal of International Studies, 20, 429-444.

King, D. E. (2008). The personal is patrilineal: Namus as sovereignty. Identities: Global Studies in Culture and Power, 15, 317-342.

Kohler Riessman, C. (2003). Women and medicalization: A new perspective. In R. Weitz (Ed.), The politics of women's bodies: Sexuality, appearance and behaviour (pp. 46-63). New York and Oxford: Oxford University Press.

Kruger, R. (1988). Focus groups: A practical guide for applied research. Newbury Park, CA: Sage Publications.

Liamputtong, P. (2005). Birth and social class: Northern Thai women's lived experiences of caesarean and vaginal birth. Sociology of Health E Illness, 27, 243-270.

Morgan, D. L. (1988). Focus groups as qualitative research: Qualitative research method series 16. Newbury Park, CA: Sage Publications.

Morgan, D. L. (Ed.). (1993). Successful focus groups: Advancing the state of art. Newbury Park, CA: Sage Publications.

Öncü, A. (1981). Turkish women in the professions: Why so many? In N. AbadanUnat (Ed.), Women in Turkish society (pp. 361-373). Leiden: E. J. Brill.

Parry, D. C. (2008). We wanted a birth experience, not a medical experience: Exploring Canadian women's use of midwifery. Health Care for Women International, 29, 784-806.

Stewart, D. W., \& Shamdasani, P. N.,(1990). Focus groups: Theory and practice, Newbury Park, CA: Sage Publications.

Tatar, M., Gunalp, S., Somunoglu, S., \& Demirol, A. (2000). Women's perceptions of caesarean section: Reflections from a Turkish teaching hospital. Social Science and Medicine, 50, 1227-1233.

Tekeli, S.. (Ed.). (1982). Kadinlarve Siyasal/Toplumsal Hayat [Women and social and political life]. İstanbul: Birikim Yayinlari.

Toktaş, S.., \& Cindoğlu, D. (2006). Modernization and gender: A study of girl's technical education in Turkey since 1927. Women's History Review, 15, 737-749.

Wilkinson, S. (2004). Focus group research. In D. Silverman (Ed.), Qualitative research (pp. 177-200). Newbury Park, CA: Sage Publications.

Yuval-Davis, N., \& Stoetzler, M. (2002). Imagined boundaries and borders: A gendered gaze. European Journal of Women's Studies, 9, 329-344.

Zadoroznyj, M. (1999). Social class, social selves and social control in childbirth. Sociology of Health and Illness, 21, 267-289. 